\title{
ZOONOTIC HELMINTHOSIS OF DOMESTIC AND WILD CARNIVORES IN THE EPIZOOTIOLOGIC TERRITORY OF SERBIA
}

\author{
Tamara Ilić ${ }^{1}$, Tamaš Petrović ${ }^{2}$, Predrag Stepanovići ${ }^{1 *}$ \\ Danica Bogunović ${ }^{1}$, Bojan Gajić ${ }^{1}$, Zoran Kulišicić \\ Marko Ristić ${ }^{4}$, Milan Hadži Milićs , Sanda Dimitrijević ${ }^{1}$ \\ ${ }^{1}$ Department of Parasitology, University of Belgrade, Faculty \\ of Veterinary Medicine, Republic of Serbia \\ ${ }^{2}$ Scientific Veterinary Institute „Novi Sad“, Novi Sad, Republic of Serbia \\ ${ }^{3}$ Department of equine, small animal, poultry and wild animal diseases, \\ University of Belgrade, Faculty of Veterinary Medicine, Republic of Serbia \\ ${ }^{4}$ Department of Animal Husbandry and Veterinary Medicine, University \\ of Niš, Faculty of Agriculture in Kruševac, Republic of Serbia \\ ${ }^{5}$ Department of Surgery, Orthopaedic and Ophthalmology, \\ University of Belgrade, Faculty of Veterinary Medicine, Republic of Serbia
}

\section{Abstract}

In the last decade, as the result of climate changes, there have been considerable changes in the parasitofauna of domestic and wild carnivores. The prevalence of the existing parasitic species has varied significantly, showing an increasing tendency, and some parasitic species not present before in this epizootiologic territory have been diagnosed as well. It is thought that the reason for such an epizootiological situation is increased presence of owners with their pet animals in the regions endemic for particular zoonotic helminthoses during summer holidays and touristic visits. This tendency has become especially conspicuous in the last several years characterized by warm winters and very hot summers due to global warming effects, with abundant atmospheric precipitation. Oral vaccination of foxes against rabies, regulated in Serbia by appropriate laws since 2010, has led to an increased number of foxes and rise of prevalence of the parasitic diseases

${ }^{1 *}$ Corresponding author: pedja@vet.bg.ac.rs; prstepanovic@gmail.com 
for which foxes represent the infection source/reservoir. Continued urbanization of Serbian cities, with the extension of urban belts into the suburbia and recreational ("weekend") settlements, lead to a closer contact of street dogs and owned dogs with foxes, which results in a significant change in the parasitic fauna of dogs. It is an additional factor, which in the chain fox - street dog - owned dog - human increases the risk and tendency for the occurrence of human infections with zoonotic endoparasites of wild and domestic carnivores. In order to reliably predict the degree of spread of particular zoonotic helminthoses in particular regions in Serbia, for which wild carnivores represent the infection source, it is necessary to institute continued monitoring of the parasitic fauna in this type of wild animals.

Key words: carnivores, parasitological screening, zoonoses, endemic parasitoses, Serbia

\title{
ZOONOZNE HELMINTOZE DOMAĆIH I DIVLJIH MESOJEDA NA EPIZOOTIOLOŠKOM PODRUČJU SRBIJE
}

\author{
Tamara Ilić', Tamaš Petrovićn , Predrag Stepanovićc ${ }^{*}$, \\ Danica Bogunović ${ }^{1}$, Bojan Gajić ${ }^{1}$, Zoran Kulišić ${ }^{1}$, \\ Marko Ristić ${ }^{4}$, Milan Hadži Milićs, Sanda Dimitrijević ${ }^{1}$ \\ ${ }^{1}$ Katedra za parazitologiju, Univerzitet u Beogradu, Fakultet \\ Veterinarske Medicine, Republika Srbija \\ ${ }^{2}$ Naučni Institut za veterinarstvo „Novi Sad“, Novi Sad, Republika Srbija \\ ${ }^{3}$ Katedra za bolesti kopitara, mesojeda, živine i divljači, Univerzitet \\ u Beogradu, Fakultet Veterinarske Medicine, Republika Srbija \\ ${ }^{4}$ Katedra za stočarstvo i veterinu, Univerzitet u Nišu, \\ Poljoprivredni Fakultet, Kruševac, Republika Srbija \\ ${ }^{5}$ Katedra za hirurgiju, ortopediju i oftalmologiju, Univerzitet u \\ Beogradu, Fakultet Veterinarske Medicine, Republika Srbija
}

\section{Kratak sadržaj}

U toku poslednje decenije u Srbiji je usled klimatskih promena došlo do značajnijih promena parazitofaune domaćih i divljih mesojeda. Prevalencija postojećih parazitskih vrsta je značajno varirala, i pokazala tendenciju povećanja, a dijagnostikovane su i neke vrste parazita koje ranije nisu 
bile prisutne na ovom epizootiološkom području. Smatra se da je razlog za ovakvu epizootiološku situaciju, povećana učestalost kretanja vlasnika sa svojim ljubimcima, u endemska područja pojedinih zoonoznih helmintoza, tokom letovanja i turističkih putovanja. Ovaj trend je naročito došao do izražaja poslednjih nekoliko godina, koje su usled globalnog zagrevanja praćene pojavom blagih zima i veoma toplih leta, sa velikom količinom atmosferskih padavina. Oralna vakcinacija lisica protiv besnila, zakonski regulisana u Srbiji od 2010. godine, uslovila je povećanje broja lisica i rast prevalencije parazitoza za koje lisice predstavljaju izvore/rezervoare infekcije. Urbanizacija gradova u Srbiji sa širenjem gradskog pojasa na periferiju i područja vikend naselja, dovodi do bliskih kontakata pasa lutalica i vlasničkih pasa sa lisicama, što je rezultiralo značajnom promenom parazitofaune pasa. To je samo dodatni faktor koji u lancu: lisica - pas lutalica - vlasnički pas - čovek, značajno povećava rizik i tendenciju za nastanak infekcije ljudi zoonoznim endoparazitima divljih i domaćih mesojeda. Da bi se predvidele razmere širenja izvesnih zoonoznih helmintoza u pojedinim regionima Srbije, za koje divlji mesojedi predstavljaju izvore infekcije, neophodno je sprovoditi kontinuiran monitoring parazitske faune ove vrste divljači.

Ključne reči: mesojedi, parazitološki skrining, zoonoze, endemične parazitoze, Srbija

\section{INTRODUCTION}

There is a great number of zoonotic endoparasites infesting carnivorous animals which represent a risk for the health of pets or human public health, and the most important among them are the species from the genera Toxocara, Echinococcus, Taenia, Dirofilaria, Dipylidium caninum, Capillaria aerophila and Thelazia callipaeda (Overgaauw and van Knapen, 2013; Marino et al., 2018; ESCCAP, 2018).

Special risk factors associated with the infection of carnivores with endoparasites are free roaming, contacts with stray dogs or cats, feeding on carcasses of paratenic hosts, feeding on intermediate host animals, age-related susceptibility, animal hormonal status (gravidity/lactation), contacts with children or immunodeficient individuals and travelling to the regions endemic for particular endoparasitoses (McNamara et al., 2018). 
As the consequence of global warming and active migrations of owners with their pet animals into the countries of this region and Europe, there has been an increase in the prevalence of helminths with zoonotic potential in domestic and wild carnivores in the territory of Serbia in the last ten years. Many of the European countries have already been registered as endemic regions for certain zoonotic nematodoses (Wall and Morgan, 2009; ESCCAP, 2018). Such an epizootiologic situation, associated with the action of the above predilection factors, has caused increased occurrence of particular cardiorespiratory, subcutaneous, ocular and intestinal parasitoses, some of which have developed endemic characteristics in the territory of Serbia as well.

Routine treatment and prevention of endoparasitoses affecting carnivores depend on legislation in individual countries and information available to doctors of veterinary medicine, the most important of which are parasite epidemiology, education of pet owners and individual risk estimations. In accordance with the ESCCAP guidelines (2018), it is recommended that every protocol of planned dehelminthization should be implemented after the following: 1) completed clinical examination; 2) coprological examination after the request by the owner; and 3) coprological diagnosis within the preparation for vaccinal immunization, in accordance with the advice given by the doctor of veterinary medicine.

\section{CARDIOPULMONARY ANDSUBCUTANEOUSDIROFILARIOSIS}

The first research of dirofilariosis in dogs in the territory of former Yugoslavia took place at the end of the last century. Up to then, there were sporadic reports in the literature about the findings of Dirofilaria immitis species in the heart of dogs (Dimitrijević, 1999), mostly as incidental autopsy observations (Milosavljević and Kulišić, 1989; Blitva-Mihajlović et al., 1995). After that, some autochthonous cases of cardiopulmonary dirofilariosis in dogs in Serbia were diagnosed (Kulišić and Milosavljević, 1994; Dimitrijević et al., 2007). The study by Tasić et al. (2008) in the territory of Vojvodina confirmed that this region was the northernmost border for cardiopulmonary dirofilariosis in dogs in the Balkans and one of European regions with the highest prevalence of subcutaneous dirofilariosis in dogs. The authors diagnosed Dirofilaria repens in $49.2 \%$ of dogs, D. immitis in $7.2 \%$, and Acanthocheilonema reconditum in $2.1 \%$ of dogs. Tasić et al. (2012) reported about the occurrence of filariosis in dogs in the territory of Pančevo and Veliko Gradište municipalities, where cardiopulmonary dirofilariosis was found in $12.3 \%$, and subcutaneous dirofilariosis in $42.6 \%$ of dogs. The first cases of $D$. immitis in dogs in the territory 
of Novi Sad were detected by Savić-Jevđenić et al. (2004). The prevalence of dirofilariosis in dogs in Vojvodina was examined by Savić et al. (2012) and they established the seroprevalence of $D$. immitis of $18 \%$ in police dogs, and in the same region in the period 2009-2013, the presence of microfilaria of D. immitis was detected in $27.6 \%$ of dogs (Savić et al., 2014). Stepanović et al. (2015) reported about their finding of D. immitis in $68 \%$ of police dogs in the Belgrade municipality, which had been declared endemic for this nematodosis several years before (Jovanović, 2012). D. immitis infection was established in $24.2 \%$ of non-owned dogs in the Belgrade municipality (Gajić, 2016). Krstić et al. (2016) established the presence of D. immitis in $12.7 \%$ of tested animals without clinical symptoms. Out of the total number of positive animals, $44 \%$ were dogs from dog shelters and $60 \%$ were pets.

The prevalence of adult forms of $D$. immitis in wild carnivores in Serbia was monitored by Penezić et al. (2014). In the period 2009-2013 they diagnosed this filaria in $7.32 \%$ of golden jackals, in $1.55 \%$ of foxes, in $1.43 \%$ of wolves and $7.69 \%$ of wild cats. Cardiopulmonary dirofilariosis was demonstrated on autopsy in 13.33\% of foxes (Gavrilović et al., 2014) and in one wolf (Gavrilović et al., 2015) from the South Banat District.

Microfilaremia established in the above host animals indicated that they represented an infection source for mosquitoes. High prevalence percentages of D. immitis of $18.52 \%$ in jackals from Romania (Ionică et al., 2016), 9.6\% in those from Bulgaria (Kirkova et al., 2011) and 7.4\% in animals from Hungary (Tolnai et al., 2014) suggest that this species of wild carnivores has an important role in the maintenance of infection. According to some authors (Otranto and Deplazes, 2019) it is necessary to elucidate the epidemiological role of foxes as well, especially bearing in mind the report on $32.3 \%$ of foxes positive to D. immitis in some of the irrigated regions in Spain (Gortázar et al., 1998).

The first study of Dirofilaria spp. in disease vectors in Serbia was performed by Kurucz et al. (2016). In the period May-August, by way of molecular analysis of grouped samples from 13 municipalities in Vojvodina, 11 species of mosquitoes were identified, and in $60 \%$ of samples the presence of Dirofilaria spp. was found. Dirofilaria immitis was diagnosed in $80 \%$ of positive grouped samples of Culex pipiens, Coquillettidia richiardii and Ochlerotatus caspius species, while D. repens was diagnosed in $20 \%$ of positive samples of Aedes vexans, Cx. pipiens and Oc. sticticus species, without any D. immitis and D. repens coinfections.

Several factors have influenced the accelerated spread of Dirofilaria spp. into European countries in which these nematodes have not been reported before. Increased duration of warm periods due to climatic change is one of 
the main factors of impact on the development, activity and seasonal survival of mosquitoes, as well as the development of larval forms of dirofilarios in disease vectors (Farkas et al., 2020). The introduction of the „Pet Travel Scheme“ in 2000 has contributed to the spread of dirofilariosis, facilitating the movement of infected, microfilaremic dogs from endemic regions to other parts of Europe (Genchi et al., 2011).

Since the prevalence of dirofilariosis in dogs in hyperendemic regions (northern parts of Serbia) exceeds 60\% (Tasić et al., 2008) human infections with the parasite should be expected as well. In the territory of Serbia and Montenegro, individual cases of human infection with $D$. repens have been reported (Kulišić et al., 1989; Kranjčić-Zec et al., 2001; Džamić et al., 2009). In people from different parts of Serbia (Pančevo, Novi Sad, Zaječar, Leskovac, Vranje, Niš, Pirot), Tasić-Otašević et al. (2014) demonstrated seropositivity of $15.4 \%$ to dirofilaria antigens. Specific antibodies against D. repens were found in $9.7 \%$, against $D$. immitis in $8.1 \%$, while antibodies against both dirofilaria species were found in $2.3 \%$ of the examined individuals. Momčilović et al. (2019) diagnosed $D$. repens in buccal mucosa in a man aged 45 years from central Serbia. A striking buccal mucosa edema along the lateral edge of the right maxilla was observed in this patient, followed by leukocytosis. Surgical extirpation was performed, and subsequent histopathological, parasitological, and molecular analysis of the specimen revealed the presence of the D. repens nematode. Of the 13 such cases reported so far worldwide, this is the first case analyzed by molecular methods.

\section{RESPIRATORY CAPILLARIOSIS}

Considering the available epizootiological data on the distribution of Capillaria aerophila species in domestic and wild carnivores in Europe, it is certain that global warming has an important impact on the distribution of this parasite (Traversa and Di Cesare, 2014; Ilić et al., 2015; Otranto and Deplazes, 2019).

Climatic change, animal migrations, destruction of animal habitats by humans, maritime transport of goods, as well as travelling of pets with their owners, all have had a significant role in the spread of this parasitosis and its global distribution (Traversa et al., 2010; Otranto et al., 2013). Changed habitats of wild animals, as the consequence of human activity, have led to a closer contact between wild and domestic animals, which caused this nematode to appear in domestic animals as well (Di Cesare et al., 2014).

The parasite has been diagnosed by way of regular coprological examinations in dogs and/or cats in Spain (Miro et al., 2004), Germany (Epe et al., 
2004), Portugal (Madeira de Carvalho et al., 2009), Romania (Mircean et al., 2010) and Italy (Traversa et al., 2009; Di Cesare et al., 2011; Traversa and Di Cesare, 2016), with evident clinical symptoms of the disease. In the period February-March 2019, in a parasitological examination of dog feces samples taken from three public city parks in Niš, C. aerophila nematode was diagnosed with the prevalence of 8-14\% (Ristić et al., 2020a).

Di Cesare et al. (2012) have described 15 genetic haplotypes of C. aerophi$l a$, out of which five were identified in pet animals in Italy and in wild animals in Serbia, and three genetic subtypes were isolated in both domestic cats and foxes in Serbia, Romania and Portugal. It should be emphasized that the genetic haplotypes described in foxes in Serbia were also found in cats and dogs in Italy and Romania. A couple of years later, it was demonstrated that different genetic haplotypes of C. aerophila could be simultaneously identified in foxes, beech martens, cats and dogs in European countries, confirming a common pattern of parasite transmission between wild animals and pets (Di Cesare et al., 2014).

The prevalence of respiratory capillariosis in red foxes in Europe is rather high, reaching 97\% in Lithuania (Bružinskaitè-Schmidhalter et al., 2012), 88\% in Norway (Davidson et al., 2006), 74.1\% in Denmark (Saeed et al., 2006), $76.2 \%$ in Poland (Karamon et al., 2018), 67-75\% in Germany (Schug et al., 2018), 66\% in Hungary (Sréter et al., 2003), 46.8\% in the Netherlands (Borgsteede, 1984) and $41.8 \%$ in Italy (Magi et al., 2015). Otranto et al. (2015) have reported about the finding of $C$. aerophilain European wild cats (33.3\%), jackals (5\%) and raccoon dogs (32\%).

Ilić et al. (2016a) have reported about the prevalence of respiratory capillariosis in foxes in particular areas in Northern, Eastern and Western Serbia, which was $49.02 \%$ in the period 2008-2012. The highest prevalence was found in foxes from the hunting grounds in the Districts of Zaječar (74.04\%) and Raška (52.63\%). Examining the endoparasitic fauna of foxes and jackals in 8 epizootiological regions in Serbia between 2010 and 2014, Ilić et al. (2016b) diagnosed C. aerophila in $23.56 \%$ of foxes aged above one year. In foxes below one year of age and in jackals, this nematode could not be identified.

There is a close association between the population of foxes and populations of dogs and cats. It is assumed that the process of urbanization and extension of urban belts into the natural habitats of foxes can lead to the opportunities for closer contacts between street dogs and cats, and foxes (Ilić et al., 2017a). The population of foxes thus represents a permanent source of infection for dogs and cats in suburbia, which is especially important for the epidemiology of respiratory capillariosis. 
It is supposed that one of the reservoirs of this zoonosis in Serbia are foxes from the territory of Vojvodina, which is additionally confirmed by a case of pulmonary capillariosis diagnosed in an individual from Bačka Palanka (Lalošević et al., 2008). Supporting to this are the results of some authors, who examined the respiratory tract of foxes from different regions of Vojvodina and diagnosed C. aerophila nematode in the trachea in $84 \%$ (Lalošević et al., 2013 ) and 30-37.50\% of foxes (Ilić et al., 2016a). These epidemiologic data additionally corroborate the hypothesis that wild carnivores represent the principal definitive hosts responsible for the transmission of C. aerophila (Otranto and Deplazes, 2019).

\section{OCULAR THELAZIOSIS}

After the original report about the finding of this nematode in dogs in Italy (Rossi and Bertaglia, 1989), T. callipaeda has swiftly spread across Europe, involving France (Dorchies et al., 2007), Switzerland (Malacrida et al., 2008), Germany (Magnis et al., 2010), Spain (Miró et al., 2011), Portugal (Vieira et al., 2012), Slovakia (Čabanová et al., 2017) and Greece (Papadopoulos et al., 2018).

The first autochthonous cases of ocular thelaziosis in dogs and cats in Serbia have been diagnosed in central, western, and southern parts of the country (Gajić et al., 2014; Tasić-Otašević et al., 2016). The isolated parasites were morphologically identified as T. callipaeda, while the molecular analyses of cytochrome oxidase-1 (cox 1) gene established the presence of h1 haplotype, so far the only established haplotype of this parasite in Europe (Gajić et al., 2014). Hadži Milić et al. (2016) reported their finding of a relatively high overall prevalence of T. callipaeda (35.52\%) in dogs in different regions of Serbia. Infected dogs in this study were from the regions in Northern (43.58\% from North Banat District and 28.94\% from South Bačka District), Central (41.83\% from Belgrade suburbia and 21.68\% from Braničevo District), Eastern (47.50\% from Bor District and 30.92\% from Zaječar District) and Southern Serbia (25.00\% from Pčinja District). Infection of wolves with T. callipaeda has recently been documented, with an overall prevalence of $38.1 \%$ (Gajić et al., 2019). This finding suggests the significance of the epizootiological role of wolves as reservoirs of infection for thelazia, although other wild carnivores' role should also be addressed in the studies.

The presence of T. callipaeda in this epizootiological area is not surprising for the geographical coordinates of Serbia, positioned between lat $41^{\circ} 53^{\prime} \mathrm{Nand}$ $46^{\circ} 11^{\prime} \mathrm{N}$ and long $18^{\circ} 49^{\prime}$ Eand $23^{\circ} 00^{\prime} \mathrm{E}$, in Southeastern Europe in the central 
part of the Balkan Peninsula. Endemic cases of ocular thelaziosis in dogs have been reported in many countries worldwide with similar geographical coordinates (between $39^{\circ}$ and $46^{\circ}$ ) (Otranto et al., 2013). For the most part, Serbia is characterized by moderate continental climate. In the South-Western part the climate varies between subtropical and continental, with the average yearly precipitation of $896 \mathrm{~mm}$, resembling those climatic conditions in the countries with reported thelaziosis cases (Hadži Milić et al., 2016).

According to the literature data, a high prevalence rate of ocular thelaziosis is present in foxes, ranging from $27.71 \%$ in Bosnia and Herzegovina (Hodžić et al., 2014), 29.38\% in Romania (Ionică et al., 2018) and 49.3\% in Southern Italy (Otranto et al., 2009), and cases of the disease have been reported in Portugal as well (Sargo et al., 2014). Furthermore, Pan-European distribution of the vector Phortica variegata (Drosophilidae, Steganinae) best explains the abilities and spreading potential of T. callipaeda (Máca and Otranto, 2014).

Circulation of the nematode across different animal species and its recent appearance in Europe is in accordance with the common genetic haplotype of T. callipaeda present in all examined wild and domestic animals (Otranto and Deplazes, 2019). Considering the fact that wild carnivores have a very broad movement area, 10 to $30 \mathrm{~km}$ for foxes (Doncaster and Macdonald, 1991) and even up to $800 \mathrm{~km}$ for wolves (Mech, 1970), they contribute considerably to the maintenance and spread of the infection. Moreover, they represent a significant infection reservoir for T. callipaeda, in both endemic and non-endemic regions (Mihalca et al., 2016), such as Great Britain, where only imported cases of thelaziosis in dogs have been reported (Graham-Brown et al., 2017) despite an endemic vector (Palfreyman et al., 2018).

In the last six years, in the countries nearby Serbia (Romania, Croatia, Bosnia and Herzegovina, Bulgaria, Austria) there have been several reported autochthonous cases of ocular thelaziosis in dogs and cats (Hodžić et al., 2014; Mihalca et al., 2015; Hodžić et al., 2019), and in Bosnia and Herzegovina in foxes as well (Hodžić et al., 2014). In 2016, the zoonotic potential of the parasite in these regions was additionally confirmed by the report of two cases of thelaziosis in humans: one in a 36-year-old man from Serbia (Tasić-Otašević et al., 2016) and one in 82-year-old man from Croatia (Paradžik et al., 2016).

Since T. callipaeda has got zoonotic potential and presents a risk for human health, it is necessary that veterinarians, doctors and ophthalmologists should include this nematodosis with ocular manifestations into their differential diagnostic considerations. Such a clinical approach is especially important in regions where ocular thelaziosis has assumed endemic character, such as in Serbia. 


\section{INTESTINAL ZOONOTIC HELMINTHOSES}

Regarding geographical distribution and clinical relevance, Toxocara canis, Ancylostomatidae and Trichuris vulpis are the most prevalent intestinal helminths affecting dogs, the importance of which is often unacknowledged by doctors of veterinary medicine, medical doctors and general public (Traversa et al., 2014). Depending on the intensity of dog infection, we should not overlook some cestodes (D. caninum and Taenia spp.), as well as trematodes (Alaria alata) and protozoans (Giardia intestinalis, Amoeba spp., and Cryptosporidium spp.) (Möhl et al., 2009; Traversa, 2012; ESCCAP, 2018). From the medical, veterinary, economic and environmental point of view, enzootic infections are the most important, the sources of which are linked to natural sites.

In the last three decades, a large number of authors have studied parasitic fauna of the digestive tract of domestic and wild carnivores from the territory of Serbia (Kulišić et al., 1992; Pavlović and Kulišić, 1994; Antanasijević et al., 1997; Dimitrijević et al., 2005; Nikolić et al., 2008; Pavlović et al., 2010; Ilić et al., 2016b; Ilić et al., 2017b; Ristić et al., 2020a).

In owned dogs, stray dogs and military working dogs in the territory of Belgrade, Nikolić et al. (2008) have found a high prevalence rate of intestinal zoonotic parasites (75.50\%). In most of these animals, the infection with $T$. vulpis nematode was diagnosed (47.00\%). In dogs and cats aged 1-8 years in the territory of Belgrade, Ilić et al. (2017b) have diagnosed toxocarosis (15.88$16.62 \%)$, ancylostomatidosis (1.87-3.80\%) and trichuriosis (0.93-4.03\%), with the finding of highest prevalence of Dipylidium caninum infection, ranging from $21.49 \%$ in cats to $24.70 \%$ in dogs.

Kostić (2016) has reported on the finding of intestinal parasites in street dogs in the territory of the city of Kruševac. Parasitological studies revealed the predominance of G. duodenalis (52.11\%) and D. caninum cestode (36.61\%). Trichuris vulpis nematode was found in one third of examined dogs (32.39\%), and T. canis (22.53\%), Taenia spp. (5.63\%), and E. granulosus (2.82\%) were diagnosed as well. In the period from September 2017 to June 2018, in a study of endoparasitoses in street dogs aged one year and over from six dog shelters in the Republic of Serbia, the highest prevalence of endoparasitic infections was found in the Shelter for street dogs and cats in Požarevac (69.54\%). In dogs below one year of age, most prevalent were toxocarosis (42.85\%) and ancylostomatidosis (26.53\%) in the Shelter for abandoned dogs in Zemun, while toxocarosis was most prevalent (35.14\%) in the Shelter for abandoned dogs in Subotica (Nišavić, 2019).

Monitoring endoparasitic fauna of foxes and jackals from eight different localities in Serbia in the period 2010-2014, Ilić et al. (2016b) have diagnosed as 
the most prevalent helminths A. alata (49.41\% in foxes and $30.00 \%$ in jackals), $T$. canis (49.41\% in foxes and $23.33 \%$ in jackals), ancylostomatids ( $40.69 \%$ in foxes and $33.33 \%$ in jackals) and T. vulpis (55.23\% in foxes and $11.66 \%$ in jackals).

Ristić et al. (2020a) have studied the prevalence of zoonotic intestinal parasites in dogs from the public parks in the city of Niš and assessed the health risks they presented for people in public places and children's playgrounds. Endoparasitoses were diagnosed with overall prevalence of $58-70 \%$. Depending on the season of the study, four most common endoparasites were T. canis (36.66-38\%), ancylostomatids (24.66-32\%), T. vulpis (20-28\%) and A. alata (28\%). Certainly worth mentioning was the fact that these helminths were identified in soil/sand samples taken from these public parks in Niš. In soil samples, a high and medium degree of contamination with T. canis ascaridid was found (14-22\%), as well as a low and medium degreeof contamination with ancylostomatids (4-12\%), medium degree of contamination with T. vulpis species (4-6\%), and medium and high degree of contamination with $A$. alata trematode (2\%). In sand samples, different degrees of contamination with helminths T. canis (26\%), ancylostomatids (8\%), T. vulpis (4\%) and A. alata (16\%) (Ristić et al., 2020b) were established. Based on the results of this parasitological screening, the authors concluded that a large number of street dogs circulated in public parks in Niš, which presented the reservoir of numerous parasitic zoonoses for owned dogs and people (particularly for preschool and school children).

The literature data suggest that $T$. canis is overall the most prevalent helminth in dogs, the prevalence of which varies between European countries from 7.5\% (Riggio et al., 2013) to 22.1\% (Habluetzel et al., 2003) in Italy; $17.72 \%$ in Spain (Martínez-Moreno et al., 2007), from 11.9\% (Papajová et al., 2014) to 45.1\% (Rudohradská et al., 2011) in Slovakia; and from 0.5\% (Ferreira et al., 2017) to $15.8 \%$ (Otero et al., 2014) in Portugal. The finding of this ascaridid always involves a high degree of risk for human populations, since after the infection its larvae migrate to individual internal organs, causing the syndrome of visceral and ocular larva migrans (Overgaauw and van Knapen, 2013).

In recent years, there has been a growing interest for the infection with $A$. alata trematode, which is very prevalent in Europe, has a potential zoonotic importance since it causes larval alariosis, and is diagnosed in a number of countries nearby Serbia, such as Croatia, Romania and Bulgaria (Lalošević et al., 2014).

A high intensity infection with this trematode has been reported to occur in intermediate hosts (wild pigs) living in the areas with high prevalence of alariosis in definitive hosts (domestic and wild carnivores). In addition to rodents, reptiles and amphibians (Esite et al., 2012), humans as well can be incidental paratenic hosts if they consume insufficiently thermally processed 
frog legs, pork (Wójcik et al., 2002; Möhl et al., 2009) or wild goose meat (Kramer et al., 1996) infected with A. alata mesocercarias.

In recent years, larval alariosis has been reported in other European countries as well. The first finding in the meat of wild pigs in Bulgaria was reported by Portier et al. (2014), when the overall prevalence of $0.6 \%$ was established. The study of the vitality of mesocercarias in products made from infected wild pig meat, prepared in a traditional fashion in Germany, has shown than only fresh products contain living mesocercarias and could be the source of infection for humans (González-Fuentes et al., 2014).

In addition to trichinellosis, wild pig meat can be the source of infection with trematode mesocercarias, so that any preparation of thermally unprocessed products (e.g., sausages) cannot be recommended. Safe for human nutrition is only well cooked wild pig meat. Bearing in mind this information, it is necessary to adjust accordingly the legislation on food safety for human consumption in Serbia (Lalošević et al., 2014).

In view of human population, zoonotic parasites from the feces of carnivores can threaten mostly dog owners or dog breeders who disregard the necessity to perform dehelminthization of their litters, children who do not wash their hands after their contacts with animals, or those with geophagic practices, agricultural workers and greengrocers (especially in semirural and rural areas where dogs freely defecate in the vicinity of vegetables).

In people in Serbia, the cases of a familial epidemic of cryptosporidiosis have been coprologically diagnosed in three immunocompetent patients (Gvozdenović et al., 2012) and there is also the case of 4.5-year-old girl in whom toxocarosis has been detected serologically (Mijatović et al., 2015). A retrospective analysis of the results of examination of feces samples from healthy people in Southern Serbia to detect possible presence of G. intestinalis revealed the highest prevalence in 2005 (4.9\%), and the lowest in 2014 (0.57\%) (Miladinović Tasić et al., 2017). Perić et al. (2017) have reported on their two cases for whom there were no anamnestic data concerning their previous travelling abroad, and in whom cutaneous larva migrans was diagnosed in 2016. The first described patient was a 72-year- old man from Western Serbia with changes localized in the chest region, and the other was a 31-year-old man from Central Serbia with changes localized in his right arm.

\section{CONCLUSION}

In order to prevent and control zoonotic helminthoses of domestic and wild carnivores it is essential that their occurrence, infection spread and maintenance should be continually monitored in foxes, dogs and humans; that the 
problem of abandoned dogs should be effectively resolved in most urban environments; that the measures to control vector populations should be undertaken; that all goods, commodities, services and traffic in international trade should be monitored; that all persons who travel with their pets to the regions endemic for these diseases or who return from these to Serbia should be monitored; that continued education of pet owners is organized; and that synchronized collaboration of appropriate services of veterinary medicine and human medicine is in place.

\section{ACKNOWLEDGEMENTS}

This paper was realized in keeping with the projects No. TR31084, No. 173001 and No. TR30188 financed by the Ministry of Education and Science of the Republic of Serbia.

\section{Authors' contributions}

IT, PT, SP, BD, GB, KZ, RM, HM and DS were participated in the design of the study, conceived of the study, and participated in its design and coordination and helped to draft the manuscript. All authors read and approved the final manuscript.

\section{Competing interests}

The author(s) declare that they have no competing interests.

\section{REFERENCES}

1. Antanasijević S., Petrović M., Ignjatović R., Kulišić Z., Pavlović I. 1997. Echinococcosis and hydatigenosis od domestic animals in Niš area-socioeconomic aspects. In Archivos internationales de la hydatidosis. XVIII International Congress of Hydatolgy, Vol XXXII, Lisboa, 286.

2. Blitva-Mihajlović G., Ralić M., Miletić B. 1995. Bolest srčane gliste. U Simpozijum Male životinje - život i zdravlje, Beograd, 34.

3. Borgsteede F.H. 1984. Helminth parasites of wild foxes (Vulpes vulpes L.) in The Netherlands. Zeitschrift für Parasitenkunde, 70, 281-285.

4. Bružinskaitė-Schmidhalter R., Šarkūnas M., Malakauskas A., Mathis A., Torgerson P.R., Deplazes P. 2012. Helminths of red foxes (Vulpes vulpes) and raccoon dogs (Nyctereutes procyonoides) in Lithuania. Parasitology, 139, 120-127. doi:10.1017/S0031182011001715 
5. Čabanová V., Kocák P., Víchová B., Miterpáková M. 2017. Firstautochthonous cases of canine thelaziosis in Slovakia: a new affected area in Central Europe. Parasites \& Vectors, 10, Article No 179. doi:10.1186/s13071-017-2128-2.

6. Davidson R.K., Gjerde B., Vikøren T., Lillehaug A., Handeland K. 2006. Prevalence of Trichinella larvae and extra-intestinal nematodes in Norwegian red foxes (Vulpes vulpes). Veterinary Parasitology, 136, 307-316. doi:10.1016/j.vetpar.2005.11.015.

7. Di Cesare A., Castagna G., Otranto D., Meloni S., Milillo P., Latrofa SM., Paoletti B., Bartoliniet R., Otranto D. 2012. Molecular detection of Capillaria aerophila, an agent of canine and feline pulmonary capillariosis. Journal of Clinical Microbiology, 50, 1958-1963. doi:10.1128/JCM.00103-12.

8. Di Cesare A., Castagna G., Meloni S., Milillo P., Latrofa S., Otranto D., Traversa D. 2011. Canine and feline infections by cardiopulmonary nematodes in central and southern Italy. Parasitology Research, 109, 1, 87-96. doi:10.1007/s00436-011-2405-5.

9. Di Cesare A., Otranto D., Latrofa SM., Veronesi F., Perrucci S., Lalosević D., Gherman MC., Traversa D. 2014. Genetic variability of Eucoleus aerophilus from domestic and wild hosts. Research in Veterinary Science, 96, 512-515. doi:10.1016/j.rvsc.2014.03.018.

10. Dimitrijević S., Ilić T., Nikolić A, Bečkei Ž. 2005. Zastupljenost parazitskih infekcija mesojeda na teritoriji grada Beograda.U Zbornik radova VII Simpozijuma „Clinica Veterinaria“, Ohrid, 326.

11. Dimitrijević S.: Dirofilarioza ante portas. U Zbornik radova Prvog savetovanja iz kliničke patologije i terapije životinja "Clinica veterinaria 99", Septembar 13-17, Budva, 58.

12. Dimitrijević S., Tasić A., Tasić S., Adamović V., Ilić T., Miladinović-Tasić N. 2007. Filariosis in dogs in Serbia. In Proceedings of the first European Dirofilaria days, edited by Genchi C., Rinaldi L., Cringoli G., Zagreb, Croatia, 201.

13. Doncaster C.P. and Macdonald D.W. 1991. Ecology and ranging behaviour of red foxes (Vulpes vulpes) in the city of Oxford. Hystrix 3, 11-20.

14. Dorchies P., Chaudieu G., Siméon L.A., Cazalot G., Cantacessi C., Otranto D. 2007. First reports of autochthonous eyeworm infection by Thelazia callipaeda (Spirurida, Thelaziidae) in dogs and cat from France. Veterinary Parasitology, 149, 294-297. doi:10.1016/j.vetpar.2007.08.005.

15. Džamić A.M., Colović I.V., Arsić-Arsenijević, V.S., Stepanović S., Boricić I., Džamić Z., Mitrović S.M., Rasić D.M., Stefanović I., Latković Z., Kranjcić-Zec I.F. 2009. Human Dirofilaria repens infection in Serbia. Journal of helminthology, 83, 2, 129-137. doi:10.1017/S0022149X09341346.

16. Epe C., Coati N., Schnieder T. (2004). Results of parasitological examinations of faecal samples from horses, ruminants, pigs, dogs, cats, hedge- 
hogs and rabbits between 1998 and 2002. Deutsche Tierarztliche Wochenschrift, 111, 6, 243-247.

17. ESCCAP. 2018. Worm control in dogs and cats. ESCCAP Guideliene 01 Third edition July 2017 - Accessed 8 Jan 2018, 40.

18. Esite Z., Deksne G., Bagrade G. 2012. Overview of Alaria alata distribution in different host animals in Latvia. Animals, health, food hygiene. In Proceedings of Conference on "Current events in veterinary research and practice”, 22-23 November, Jelgava, Latvia, 36-39.

19. Farkas R., Mag V., Gyurkovszky M., Takács N., Vörös K., Solymosi N. 2020. The current situation of canine dirofilariosis in Hungary. Parasitology Research, 119, 129-135. https://doi.org/10.1007/s00436-019-06478-5.

20. Ferreira A., Alho A.M., Otero D., Gomes L., Nijsse R., Overgaauw PA., Madeira de Carvalho L. 2017. Urban dog parks as sources of canine parasites: contamination rates and pet owner behaviours in Lisbon, Portugal. Journal of Environmental and Public Health, Article ID 5984086, 1-7. doi:10.1155/2017/5984086.

21. Gajić B. 2016. Prevalencija vektorski prenosivih bolesti kod nevlasničkih pasa na području Beograda. Akademski specijalistički rad, Fakultet veterinarske medicine,Univerzitet u Beogradu, 51.

22. Gajić B., Bogunović D., Stevanović J., Kulišić Z., Simeunović P., Stanimirović Z. 2014. Canine and feline thelaziosis caused by Thelazia callipaeda in Serbia. Acta Veterinaria-Beograd, 64, 4, 447-455. doi:10.2478/acve-2014-0042.

23. Gajić B., Bugarski-Stanojević V., Penezić A., Kuručki M., Bogdanović N., Ćirović D. 2019. First report of eyeworm infection by Thelazia callipaeda in gray wolf (Canis lupus) from Serbia. Parasitology Research, 118, 35493553. doi:10.1007/s00436-019-06519-z.

24. Gavrilović P., Blitva-Robertson G., Özvegy J., Kiskároly F., Becskei Zs. 2015. Case Report of dirofilariasis in grey wolf in Serbia. Acta Parasitologica, 60, 175-178. doi:10.1007/BF03406010.

25. Gavrilović P., Vasković N., Živulj A., Jovanović M. 2014. Examination of D. immitis presence in foxes in Serbia (in Serbian with English summary). Veterinarski Glasnik, 68, 5-6, 387-393. doi:10.2298/VETGL1406387G.

26. Genchi C., Mortarino M., Rinaldi L., Cringoli G., Traldi G., Genchi M. 2011. Changing climate and changing vector-borne disease distribution: the example of Dirofilaria in Europe. Veterinary Parasitology, 176, 295299. doi:10.1016/j.vetpar.2011.01.012.

27. González-Fuentes H., Hamedy A., Borell E., Luecker E., Riehn K. 2014. Tenacity of Alaria alata mesocercariae in homemade German meat products. International Journal of Food Microbiology, 176, 9-14. doi:10.1016/j.ijfoodmicro.2014.01.020. 
28. Gortázar C., Villafuerte R., Lucientres J., Fernández-de-Luco D. 1998. Habitat related differences in helminth parasites of red foxes in the Ebro valley. Veterinary Parasitology, 80, 75-81. doi:10.1016/s0304-4017(98)00192-7.

29. Graham-Brown J., Gilmore P., Colella V., Moss L., Dixon C., Andrews M., Arbeid P., Barber J., Timofte D., Mc Garry J., Otranto D., Williams D. 2017. Three cases of imported eyeworm infection in dogs: a new threat for the United Kingdom. Veterinary Record, 181, 346. doi:10.1136/vr.104378.

30. Gvozdenović E., Mitrović M., Dakić Z., Stojković-Švirtlih N., Dulović O. 2012. Family outbreak of cryptosporidiosis in Serbia: Case report. Srpski arhiv za celokupno lekarstvo, 140, 9-10, 653-657. doi:10.2298/ SARH1210653G.

31. Habluetzel A., Traldi G., Riggieri S., Attili AR., Scuppa P., Marchetti R., Menghini G., Esposito F. 2003. An estimation of Toxocara canis prevalence in dogs, environmental egg contamination and risk of human infection in the Marche region of Italy. Veterinary Parasitology, 113, 243-252. doi:10.1016/S0304-4017(03)00082-7.

32. Hadži-Milić M., Ilić T., Stepanović P., Đorđević J., Dimitrijević S. 2016. Serbia: Another endemic region for canine ocular thelaziosis. Medycyna Weterynaryjna, 72, 9, 558-563. doi:10.21521/mw.5561.

33. Hodžić A., Latrofa MS., Annoscia G., Alić A., Beck R., Lia RP., DantasTorres F., Otranto D. 2014. The spread of zoonotic Thelazia callipaeda in the Balkan area. Parasites \& Vectors, 7, 352. doi:10.1186/1756-3305-7-352.

34. Hodžić A., Payer A., Duscher G.G. 2019. The first autochthonous case of feline ocular thelaziosis in Austria. Parasitology Research, 118, 1321-1324. doi:10.1007/s00436-019-06275-0.

35. Ilić T., Mandić M., Stepanović P., Dimitrijević S. 2015. Dog and cat respiratory capilariasis - clinical, parasitological and epidemiological significance. Veterinarski Glasnik, 69, 5-6, 417-428. doi:10.2298/VETGL1506417I.

36. Ilić T., Becskei Zs., Tasić A., Stepanović P., Radisavljević K., Đurić B., Dimitrijević S. 2016a. Red foxes (Vulpes vulpes) as reservoirs of respiratory capillariosis in Serbia. Journal of Veterinary Research, 60, 153-157. doi:10.1515/jvetres-2016-0022.

37. Ilić T., Becskei Zs., Petrović T., Polaček V., Ristić B., Milić S., Stepanović P., Radisavljević K., Dimitrijević S. 2016b. Endoparasitic fauna of red foxes (Vulpes vulpes) and golden jackals (Canis aureus) in Serbia. Acta Parasitologica, 61, 2, 389-396. doi: 10.1515/ap-2016-0051.

38. Ilić T., Mandić M., Stepanović P., Dimitrijević S. 2017a. The cardiopulmonary metastrongylidosis of dogs and cats contribution to diagnose. Veterinarski Glasnik, 71, 2, 69-86. doi:10.2298/VETGL170310010I. 
39. Ilić T., Kulišić Z., Antić N., Radisavljević K., Dimitrijević S. 2017b. Prevalence of zoonotic intestinal helminths in pet dogs and cats in the Belgrade area. Journal of Applied Animal Research, 45, 1, 204-208. doi:10.1080/097 12119.2016.1141779.

40. Ionică A.M., Matei I.A., D’Amico G., Daskalaki A.A., Juránková J., Ionescu DT., Mihalca AD., Modrý D., Gherman C.M. 2016. Role of golden jackals (Canis aureus) as natural reservoirs of Dirofilaria spp. in Romania. Parasites \& Vectors, 9, 240. doi:10.1186/s13071-016-1524-3.

41. Ionică A.M., Deak G., Matei I.A., D’Amico G., Cotuţiu V.D., Gherman C.M., Mihalca A.D. 2018. Thelazia callipaeda, an endemic parasite of red foxes (Vulpes vulpes) in Western Romania. Journal of Willife Diseases, 54, 829-833. doi:10.7589/2017-10-251.

42. Jovanović M. 2012. Prilog poznavanju dijagnostike, terapije i profilakse dirofilarioze pasa na teritoriji Grada Beograda. Academic specialisation (on post graduate course for pathology and therapy of small animals), Faculty of Veterinary Medicine, University of Belgrade, Serbia, 76.

43. Karamon J., Dąbrowska J., Kochanowski M., Samorek-Pieróg M., Sroka J., Różycki M., Cencek T. 2018. Prevalence of intestinal helminths of red foxes (Vulpes vulpes) in central Europe (Poland): a significant zoonotic threat. Parasites \& Vectors, 11, 436. doi:10.1186/s13071-018-3021-3.

44. Kirkova Z., Raychev E., Georgieva D. 2011. Studies on feeding habits and parasitological status of red fox, golden jackal, wild cat and stone marten in Sredna Gora, Bulgaria. Life Science Journal, 5, 264-270.

45. Kostić B.2016. Ekološki i društveni značaj rešavanja problema napuštenih pasa na teritoriji grada Kruševca. Doktorska disertacija, Fakultet za ekonomiju i inžinjerski menadžment, Univerzitet Privredna akademija, Novi Sad, 187.

46. Kramer M.H., Eberhard M.L., Blankenberg T.A. 1996. Respiratory symptoms and subcutaneous granuloma caused by mesocercariae: a case report. American Journal of Tropical Medicine and Hygiene, 55, 447-448. doi:10.4269/ajtmh.1996.55.447.

47. Kranjčić-Zec I., Džamić A., Arsić V., Mitrović S. 2001. Human infections by the nematodes of the Dirofilaria sp. In Proceedings of Scientific Meeting: Tissue helminthoses of man and animals (in Serbian), 11-20.

48. Krstić M., Gabrielli S., Ignjatović M., Savić S., Cancrini G., Ranđelović G., Momčilović S., Stojnev S., Otašević S. 2016. An appraisal of canine and human cases reveals an endemic status of dirofilariosis in parts of Serbia, Molecular and Cellular Probes, 31, 37-41. doi:10.1016/j.mcp.2016.08.005.

49. Kulišić Z., Kranjčić-Zec I., Mitrović S., Radojičić B. 1989. Novi slučaj dirofilarioze ljudi u Jugoslaviji. U 6. Kongres mikrobiologov Jugoslavije, Maribor, 124. 
50. Kulišić Z., Pavlović I., Nikolić A., Veljović T., Kokoškov N., Sikimić P., Bojkovski J. 1992. Paraziti digestivnog trakta pasa na području Beograda. U Zbornik kratkih sadržaja V Savetovanja veterinara Srbije, Kopaonik, 90.

51. Kulišić, Z. and Milosavljević, P. 1994. Savremene metode dijagnostike dirofilarioze pasa. Veterinarski Glasnik, 48, 9, 745-749.

52. Kurucz K., Kepner A., Krtinic B., Zana B., Földes F., Banyai K., Oldal M, Jakab F., Kemenesi G. 2016. First molecular identification of Dirofilaria spp. (Onchocercidae) in mosquitoes from Serbia. International Journal of Infectious Diseases, 53, 156. doi:10.1016/j.ijid.2016.11.381.

53. Lalošević D., Lalošević V., Klem I., Stanojev-Jovanović D., Pozio E. 2008. Pulmonary capillariasis miming bronchial carcinoma. American Journal of Tropical Medicine and Hygiene, 78, 14-16.

54. Lalošević V., Lalošević D., Čapo I., Simin V., Galfi A., Traversa D. 2013. High infection rate of zoonotic Eucoleus aerophilus infection in foxes from Serbia. Parasite, 20, Article No3, 1-5. doi:10.1051/parasite/2012003.

55. Lalošević D., Lalošević V., Putić S., Simin S., Kuruca Lj. 2014. Alaria alata mezocerkarije u mesu divlje svinje, novoregistrovani patogen u Srbiji. MD - Medical Data, 6, 4, 363-365.

56. Máca J. and Otranto D. 2014. Drosophilidae feeding on animals and the inherent mystery of their parasitism. Parasites \& Vectors, 7, 516. doi:10.1186/ s13071-014-0516-4.

57. Madeira de Carvalho LM. Pereira da Fonseca LM. Gomes L., Meireles JM. 2009. Lungworms in domestic and wild carnivores in Portugal: rare parasites or rarely diagnosed? In Proceedings of the Bayer Angiostrongylosis Forum, 19th Annual Congress of the European College of Veterinary Internal Medicine - Companion Animals, Porto, Portugal, 28.

58. Magi M., Guardone L., Prati M.C., Mignone W., Macchioni F. 2015. Extraintestinal nematodes of the red fox Vulpes vulpes in north-west Italy. Journal of Helminthology, 89, 4, 506-511. doi:10.1017/S0022149X1400025X.

59. Magnis J., Naucke T.J., Mathis A., Deplazes P., Schnyder M. 2010. Local transmission of the eye worm Thelazia callipaeda in southern Germany. Parasitology Research, 106, 715-717. doi:10.1007/s00436-009-1678-4.

60. Malacrida F., Hegglin D., Bacciarini L., Otranto D., Nägeli F., Nägeli C., Bernasconi C., Scheu U., Balli A., Marenco M., Togni L., Deplazes P., Schnyder M. 2008. Emergence of canine ocular thelaziosis caused by Thelazia callipaeda in southern Switzerland. Veterinary Parasitology, 157, 321-327. doi:10.1016/j.vetpar.2008.07.029.

61. Marino V., Gálvez R., Colella V., Sarquis J., Checa R., Montoya A., Barrera PJ., Domínguez S., Lia PR., Otranto D., Miró G. 2018. Detection of Thelazia 
callipaeda in Phortica variegata and spread of canine thelaziosis to new areas in Spain. Parasites \& Vectors, 11, Article No195, 1-10. doi:10.1186/ s13071-018-2773-0.

62. Martínez-Moreno F.J., Hernández S., López-Cobos E., Becerra C., Acosta I., Martínez-Moreno A. 2007. Estimation of canine intestinal parasites in Córdoba (Spain) and their risk to public health. Veterinary Parasitology, 143, 1, 7-13. doi:10.1016/j.vetpar.2006.08.004.

63. McNamara J., Drake J., Wiseman S., Wright J. 2018. Survey of European pet owners quantifying endoparasitic infection risk and implications for deworming recommendations. Parasites \& Vectors, 11, 571. doi:10.1186/ s13071-018-3149-1.

64. Mech L.D. 1970. The wolf: the ecology and behavior of an endangered species. The Natural History Press, Garden City, New York.

65. Mihalca AD., D’Amico G., Scurtu I., Chirilă R., Matei IA., Ionică AM. 2015. Further spreading of canine oriental eyeworm in Europe: first report of Thelazia callipaeda in Romania. Parasites \& Vectors, 8, 48. doi:10.1186/ s13071-015-0663-2.

66. Mihalca A.D., Ionică A.M., D’Amico G., Daskalaki A.A., Deak G., Matei I.A., Șimonca V., Iordache D., Modrý D., Gherman C.M. 2016. Thelazia callipaeda in wild carnivores from Romania: new host and geographical records. Parasites \& Vectors, 9, 350. doi:10.1186/s13071-016-1628-9.

67. Mijatović D., Ćalasan N., Simin V., Lalošević D. 2015. Nadzor pacijenta sa toksokarijazom - Prikaz slučaja (In Serbian). MD - Medical Data 7, 4, 327-329.

68. Miladinović Tasić N., Đorđević N., Zdravković D., Tasić A. 2017. Prevalencija đardioze kod asimptomatskih osoba na području grada Niša (In Serbian). Acta Medica Medianae, 56, 3, 48-54. doi:10.5633/amm.2017.0308.

69. Milosavljević P. and Kulišić Z. 1989. Prvi slučajevi dirofilarioze pasa u Jugoslaviji. Veterinarski Glasnik, 43, 1, 71-76.

70. Mircean V., Titilincu A., Vasile C. 2010. Prevalence of endoparasites in household cat (Felis catus) populations from Transylvania (Romania) and association with risk factors. Veterinary Parasitology, 171, 163-166. doi:10.1016/j.vetpar.2010.03.005.

71. Miro G., Montoyaa A., Jimenez S., Frisuelosa C., Mateoa M., Fuentes I. 2004. Prevalence of antibodies to Toxoplasma gondii and intestinal parasites in stray, farm and household cats in Spain. Veterinary Parasitology, 3, 249-255. doi:10.1016/j.vetpar.2004.08.015.

72. Miró G., Montoya A., Hernández L., Dado D., Vázquez M.V., Benito M., Villagrasa M., Brianti E., Otranto D. 2011. Thelazia callipaeda infection in dogs: a new parasite for Spain. Parasites \& Vectors, 4, 148. doi:10.1186/17563305-4-148. 
73. Momčilović S., Gabrielli S., Golubović M., Smilić T., Krstić M., Đenić S., Ranđelović M., Tasić-Otašević S. 2019. Human dirofilariosis of buccal mucosa - first molecularly confirmed case and literature review. Parasitology International, 73, Article ID 101960, 1-7. doi:10.1016/j.parint.2019.101960.

74. Möhl K., Grosse K., Hamedy A., Wüste T., Kabelitz P., Lücker E. 2009. Biology of Alaria alata and human exposition risk to Alaria mesocercaria - a review. Parasitology Research, 105, Article No 1. doi:10.1007/s00436-0091444-7.

75. Nikolić A., Dimitrijević S., Katić-Radivojević S., Klun I., Bobić B., Djurković-Djaković O. 2008. High prevalence of intestinal zoonotic parasites in dogs from Belgrade, Serbia - Short communication. Acta Veterinaria Hungarica, 56, 3, 335-340. doi:10.1556/avet.56.2008.3.7.

76. Nišavić U. 2019. Endoparazitoze pasa u odabranim prihvatilištima na području Srbije. Akademski specijalistički rad, Fakultet veterinarske medicine, Univerzitet u Beogradu, 62.

77. Otero D., Nijsse R., Gomes L., Alho A., Overgaauw P., Hoek D., Madeira de Carvalho LM. 2014. Prevalência de ovos de Toxocara spp., no solo de parquespublicos da area da Grande Lisboa, Portgal - resultadospreliminares. (In Portuguese). Acta Parasitologica Portuguesa, 20, 1-2, 47-50.

78. Otranto D. and Deplazes P. 2019. Zoonotic nematodes of wild carnivores. International Journal for Parasitology: Parasites and Wildlife, 9, 370-383. doi:10.1016/j.ijppaw.2018.12.011.

79. Otranto D., Cantacessi C., Pfeffer M., Dantas-Torres F., Brianti E., Deplazes P., Genchi C., Guberti V., Capelli G. 2015. The role of wild canids and felids in spreading parasites to dogs and cats in Europe. Part I: Protozoa and tick-borne agents. Veterinary Parasitology, 213, 12-23. doi:10.1016/j. vetpar.2015.04.022.

80. Otranto D., Dantas-Torres F., Brianti E., Traversa D., Petrić D., Genchi C., Capelli G. 2013. Vector-borne helminths of dogs and humans in Europe. Parasites \& Vectors, 6, 16. doi:10.1186/1756-3305-6-16.

81. Otranto D., Dantas-Torres F., Mallia E., Di Geronimo P.M., Brianti E., Testini G., Traversa D., Lia R.P. 2009. Thelazia callipaeda (Spirurida, Thelaziidae) in wild animals: report of new host species and ecological implications. Veterinary Parasitology, 166, 262-267. doi:10.1016/j.vetpar.2009.08.027.

82. Overgaauw P.A. and van Knapen F. 2013. Veterinary and public health aspects of Toxocara spp. Veterinary Parasitology, 193, 398-403. doi:10.1016/j. vetpar.2012.12.035.

83. Palfreyman J., Graham-Brown J., Caminade C., Gilmore P., Otranto D., Williams D.J.L. 2018. Predicting the distribution of Phortica variegata and 
potential for Thelazia callipaeda transmission in Europe and the United Kingdom. Parasites \& Vectors, 11, Article No 72. doi:10.1186/s13071-0182842-4.

84. Papadopoulos E., Komnenou A., Thomas A., Ioannidou E., Colella V., Otranto D. 2018. Spreading of Thelazia callipaeda in Greece. Transboundary and Emerging Diseases, 65, 248-252. doi:10.1111/tbed.12626.

85. Papajová I., Pipiková J., Papaj J., Ĉiţmár A. 2014. Parasitic contamination of urban and rural environments in the Slovak Republic: dog's excrements as a source. Helminthologia, 51, 4, 273-280. doi:10.2478/s11687-014-0241-8.

86. Paradžik M.T., Samardžić K., Živičnjak T., Martinković F., Janjetović Ž., Miletić-Medved M. 2016. Thelazia callipaeda: first human case of thelaziosis in Croatia. Wiener Klinische Wochenschrift, 128, 221-223. doi:10.1007/ s00508-015-0889-1.

87. Pavlović I., Kulišić Z., Ljubić B., Radivojević S., Terzin V., Stokić-Nikolić S., Rajković M., Anđelić-Buzadžić G. 2010. Raširenost parazitskih infekcija pasa i kontaminiranost javnih površina-rizik nastanka humanih infekcija. U Zbornik VII Kongresa mikrobiologa Srbije, Beograd, 1-2.

88. Pavlović I. and Kulišić Z. 1994. Prevalencija askarida kod lisica i pasa na području Beograda. U Zbornik kratkih sadržaja VII Savetovanja veterinara Srbije, Zlatibor, 28.

89. Penezić A., Selaković S., Pavlović I., Ćirović D. 2014. First findings and prevalence of adult heartworms (Dirofilaria immitis) in wild carnivores from Serbia. Parasitology Research, 113, 3281-3285. doi:10.1007/s00436014-3991-9.

90. Perić J., Lekić B., Reljić V., Ćirković L., Škiljević D. 2017. Cutaneous larva migrans - report of 2 new cases locally acquired in Serbia. Serbian Journal of Dermatology and Venerology, 9, 4, 149-153. doi:10.1515/sjdv-20170016.

91. Portier J., Vallée I., Lacour S.A., Martin-Schaller R., Ferté H., Durand B. 2014. Increasing circulation of Alaria alata mesocercaria in wild boar populations of the Rhine valley, France, 2007-2011. Veterinary Parasitology, 199, 3-4, 153-159. doi:10.1016/j.vetpar.2013.09.029.

92. Riggio F., Mannella R., Ariti G., Perrucci S. 2013. Intestinal and lung parasites in owned dogs and cats from central Italy. Veterinary Parasitology, 193, 1-3, 78-84. doi:10.1016/j.vetpar.2012.11.026.

93. Ristić M., Dimitrijević S., Višnjić A., Bogunović D., Gajić B., Stojanović M., Ilić T. 2020a. Dogs from public city parks as a potential source of environmental pollution by zoonotic parasites. Indian Journal of Animal Sciences, April 2020 issue 90 (4): 35-42, 2020a. In press. 
94. Ristić M., Miladinović-Tasić N., Dimitrijević S., Nenadović K., Bogunović D., Stepanović P., Ilić T. 2020b. Soil and sand contamination with canine intestinal parasite eggs as a risk factor for human health in public parks in Niš (Serbia). Helminthologia, 57, 2, 109-119. doi:10.2478/helm-2020-0018.

95. Rossi L. and Bertaglia P.P. 1989. Presence of Thelazia callipaeda Railliet \& Henry, 1910, in Piedmont, Italy. Parassitologia, 31, 167-172.

96. Rudohradská P., Papajová I., Juriš P. 2011. Pets as a source of parasitic soil contamination in the settlements of marginal ised groups of inhabitants. Folia Veterinaria, 55, 1, 33-35.

97. Saeed I., Maddox-Hyttel C., Monrad J., Kapel C.M.O. 2006. Helminths of red foxes (Vulpes vulpes) in Denmark. Veterinary Parasitology, 139, 1-3, 168-179. doi:10.1016/j.vetpar.2006.02.015.

98. Savić S., Vidić B., Grgić Z., Potkonjak A., Spasojević Lj. 2014. Emerging Vector-Borne Diseases - Incidence through Vectors. Frontiers in Public Health, 2, 267. doi:10.3389/fpubh.2014.00267.

99. Savić S., Vidić B., Grgić Ž., Jurišić A., Curčić V., Ružić M., Lolić Z. 2012. Canine vector borne zoonozes in Vojvodina. Arhiv veterinarske medicine, 5,1, 77-87. doi:10.46784/e-avm.v5i1.164.

100. Savić-Jevđenić S., Vidić B., Grgić Ž., Milovanović A. 2004. Brza dijagnostika dirofilarioze pasa u regionu Novog Sada. Veterinarski Glasnik, 58, 5-6, 693-698.

101. Schug K., Krämer F., Schaper R., Hirzmann J., Failing K., Hermosilla C., Taubert A. 2018. Prevalence survey on lungworm (Angiostrongylus vasorum, Crenosoma vulpis, Eucoleus aerophilus) infections of wild red foxes (Vulpes vulpes) in central Germany. Parasites \& Vectors, 11, 85. doi:10.1186/s13071-018-2672-4.

102. Sréter T., Széll Z., Marucci G., Pozio E., Varga I. 2003. Extraintestinal nematode infections of red foxes (Vulpes vulpes) in Hungary. Veterinary Parasitology, 115, 329-334. doi:10.1016/S0304-4017(03)00217-6.

103. Stepanović P., Ilić T., Krstić N., Dimitrijević S. 2015. Efficiency of modified therapeutic protocol in the treatment of some varieties of canine cardiovascular dirofilariasis. Bulletin of Veterinary Institute in Pulawy, 59, 505-509, 2015. doi:10.1515/bvip-2015-0075.

104. Tasić A., Rossi L., Tasić S., Miladinović-Tasić N., Ilić T., Dimitrijević S. 2008. Survey of canine dirofilariasis in Vojvodina. Serbia. Parasitology Research, 103, 1297-1302. doi:10.1007/s00436-008-1132-z.

105. Tasić A., Tasić-Otašević S., Gabrielli S., Miladinović-Tasić N., Ignjatović A., Dornević J., Dimitrijević S., Cancrini G. 2012. Canine dirofilariosis in two non-investigated areas of Serbia: epidemiological and genetical 
aspects. Vector-Borne and Zoonotic Diseases, 12, 1031-1035. doi:10.1089/vbz.2011.0949.

106. Tasić-Otašević S., Gabrielli S., Trenkić-Božinović M., Petrović A., Gajić B., Colella V., Momčilović S., Cancrini G. Otranto D. 2016. Eyeworm infections in dogs and in a human patient in Serbia: a one health approach is needed. Comparative Immunology, Microbiology \& Infectious Diseases, 45, 20-22. doi:10.1016/j.cimid.2016.01.003.

107. Tasić-Otašević S.A., Gabrielli S.V., Tasić A.V., Miladinović-Tasić N.L., Kostić J.T., Ignjatović A.M., Popović-Dragonjić L.D., Milošević Z.G., Arsić-Arsenijević S., Cancrini G.A. 2014. Seroreactivity to Dirofilaria antigens in people from different areas of Serbia. BMC Infectious Diseases, 14, 68. doi:10.1186/1471-2334-14-68.

108. Tolnai Z., Széll Z., Sproch Á., Szeredi L., Sréter T. 2014. Dirofilaria immitis: an emerging parasite in dogs, red foxes and golden jackals in Hungary. Veterinary Parasitology, 203, 3-4, 339-342. doi:10.1016/j.vetpar.2014.04.004.

109. Traversa D., Di Cesare A., Milillo P., Iorio R., Otranto D. 2009. Infection by Eucoleus aerophilus in dogs and cats: is another extra-intestinal parasitic nematode of pets emerging in Italy? Research in Veterinary Science, 87, 270-272. doi:10.1016/j.rvsc.2009.02.006.

110. Traversa D. and Di Cesare A. 2014. Cardio-pulmonary parasitic nematodes affecting cats in Europe: unraveling the past, depicting the present, and predicting the future. Frontiers in Veterinary Science, 1, 11, 1-9. doi:10.3389/fvets.2014.00011.

111. Traversa D. and Di Cesare A. 2016. Diagnosis and managament of lungworm infections in cats: Cornerstones, dilemmas and new avenues. Journal of Feline Medicine and Surgery, 18, 7-20. doi:10.1177/1098612X15623113.

112. Traversa D., Di Cezare A., Conboy G. 2010. Canine and feline cardiopulmonary parasitic nematodes in Europe: emerging and understimated. Parasites \& Vectors, 3, 62. doi:10.1186/1756-3305-3-62.

113. Traversa D., Frangipane di Regalbono A., Di Cesare A., La Torre F., Drake J., Pietrobelli M. 2014. Environmental contamination by canine geohelminths. Parasites \& Vectors, 7, 67. doi:10.1186/1756-3305-7-67.

114. Traversa D. 2012. Pet roundworms and hookworms: A continuing need for global worming. Parasites \& Vectors, 5, 91. doi:10.1186/1756-3305-5-91.

115. Vieira L., Rodrigues F.T., Costa Á., Diz-Lopes D., Machado J., Coutinho T., Tuna J., Latrofa M., Cardoso L., Otranto D. 2012. First report of canine ocular thelaziosis by Thelazia callipaeda in Portugal. Parasites \& Vectors, 5, 124. doi:10.1186/1756-3305-5-124. 
116. Wall R. and Morgan E. 2009. Veterinary parasitology and climate change. Veterinary Parasitology, 163, 263. doi:10.1016/j.vetpar.2009.03.023.

117. Wójcik A.R., Franckiewicz-Grygon B., Żbikowska E. 2002. Badania nad przywrą Alaria alata (Goeze, 1782) [Article in Polish]. Medycyna Weterynaryjna, 58, 517-519.

Submitted: 10.05.2020.

Accepted: 19.06.2020. 